\title{
Burkitt's Lymphoma Is a Malignancy of Mature B Cells Expressing Somatically Mutated V Region Genes
}

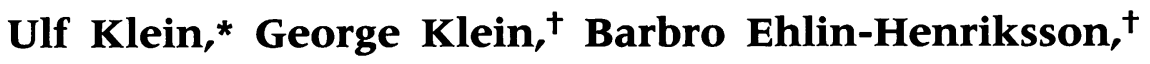 \\ Klaus Rajewsky,* and Ralf Küppers* \\ *Institute for Genetics, University of Cologne, Cologne, Germany \\ ${ }^{\dagger}$ Department of Tumor Biology, Karolinska Institute, Stockholm, Sweden
}

\begin{abstract}
Background: The developmental stage from which stems the malignant B cell population in Burkitt's lymphoma (BL) is unclear. An approach to answering this question is provided by the sequence analysis of rearranged immunoglobulin (Ig) variable region (V) genes from BL for evidence of somatic mutations, together with a phenotypic characterization. As somatic hypermutation of Ig $\mathrm{V}$ region genes occurs in germinal center B cells, somatically mutated Ig genes are found in germinal center B cells and their descendents.

Materials and Methods: Rearranged $V_{\kappa}$ region genes from $10 \kappa$-expressing sporadic and endemic BL-derived cell lines (9 IgM and 1 IgG positive) and three $\kappa$-expressing endemic BL biopsy specimens were amplified by polymerase chain reaction and sequenced. In addition, $\mathrm{V}_{\mathrm{H}}$ region gene sequences from these cell lines were determined.
\end{abstract}

Results: All BL cell lines and the three biopsy specimens carried somatically mutated $\mathrm{V}$ region genes. The average mutation frequency of rearranged $\mathrm{V}_{\kappa}$ genes from eight BL cell lines established from sporadic BL was $1.8 \%$. A higher frequency $(6 \%)$ was found in five endemic cases (three biopsy specimens and two BL cell lines).

Conclusions: The detection of somatic mutations in the rearranged $\mathrm{V}$ region genes suggests that both sporadic and endemic BL represent a B-cell malignancy originating from germinal center B cells or their descendants. Interestingly, the mutation frequency detected in sporadic $B L$ is in a range similar to that characteristic for IgM-expressing B cells in the human peripheral blood and for $\mu$ chain-expressing germinal center B cells, whereas the mutation frequency found in endemic BL is significantly higher.

\section{INTRODUCTION}

Burkitt's lymphoma (BL) is a high-grade B cell lymphoma that is cytogenetically characterized by translocation of the c-myc proto-oncogene on chromosome 8 into either of the three Ig gene loci on chromosome 14 (IgH locus), 2 (Ig $\kappa$ locus) or 22 (Ig $\lambda$ locus) $(1,2)$. Furthermore, in the endemic form of the disease, found predominantly in African children, more than $90 \%$ of the

Address correspondence and reprint requests to: Ralf Küppers, University of Cologne, LFI-Gebäude, E4 R706, JosefStelzmannstrasse 9, 50931 Cologne, Germany. cases test positive for the Epstein Barr virus (2). This virus is present in only $30-40 \%$ of sporadic tumors of Europeans and from nonendemic areas in North Africa (1). Endemic and sporadic BL also differs in the patterns of chromosomal breakpoint locations: in sporadic $\mathrm{BL}$, translocations are predominantely found within the c-myc gene and outside the $\mu$ switch region, whereas the reverse is true for endemic BL (3).

The origin of the malignant $\mathrm{B}$ cell giving rise to $\mathrm{BL}$ is controversial. In a recent proposal for a revised lymphoma classification, the normal counterpart of the tumor cells in BL is classified 
as "B cell of unknown differentiation stage" (4). Based on the expression of germinal center (GC) $B$ cell-associated surface antigens (CD10, CD 38, and CD77) a GC-derivation of BL has been proposed $(5,6)$. Since Ig heavy chain class switch is known to take place in the GC-microenvironment $(7,8)$, though not exclusively $(9)$, the finding that in several cases the breakpoint of translocation at chromosome 14 is located in the $s \mu$ switch region was taken as support for this hypothesis (10). However, others consider BL to be derived from $\mathrm{B}$ lymphocytes corresponding to earlier stages of B cell development (11). Several lines of evidence are compatible with a derivation of BL tumor cells from immature or antigeninexperienced (naive) B cells: (1) the surface markers $\mathrm{CD} 10$ and $\mathrm{CD} 38$ are not exclusively found on GC B cells but also on immature B cells in the bone marrow $(12,13) ;(2)$ the existence of translocations in both the light chain loci and the heavy chain $\mathrm{J}_{\mathrm{H}}$ locus suggests that the translocation occurred during $\mathrm{V}$ gene rearrangement (i.e., in the bone marrow); (3) most $\mathrm{BL}$ and $\mathrm{BL}$ cell lines express $\operatorname{Ig} M$ and not $\operatorname{IgG}$ or $\operatorname{IgA}(1)$, the isotypes characteristic for "classical" GC-derived memory B cells (14); and (4) the fact that BL is primarily an extra-nodal disease has been taken as an indication of a non-GC derivation of this tumor (1).

A sequence analysis of rearranged $\mathrm{V}$ region genes for somatic mutation is a reliable approach to reveal the stage of cellular maturation of the tumor $B$ cells in $\mathrm{BL}$ : naive $\operatorname{IgM}^{+} \operatorname{IgD}^{+} \mathrm{B}$ cells express unmutated $V$ region genes (15-17). The process of somatic hypermutation is active in, and probably restricted to, antigen-activated $\mathrm{B}$ cells proliferating in the microenvironment of the GC in secondary lymphoid organs (18). Therefore, somatically mutated $\mathrm{V}$ genes are found in GC B cells and GC-derived memory B cells $(16-18)$.

Expressed $\mathrm{V}$ region genes have previously been cloned and sequenced from several BL cell lines (19-26) and from one BL biopsy (27). Furthermore, $\mathrm{V}$ gene sequences of five cell lines established from AIDS-associated BL were determined (28-30). However, in most of the studies on classical BL lines an assignment of somatic mutations was hampered by the fact that the corresponding germline genes could not be unequivocally identified. Somatically mutated $V$ region genes were found in AIDS patients-derived $\mathrm{BL}$ lines $(28-30)$. However, the relevance of this finding for classical BL is unclear. Thus, whether classical BL express somatically mutated $\mathrm{V}$ region
TABLE 1. Oligonucleotides used for the amplification of human $V_{H}$ region genes ${ }^{a}$

\begin{tabular}{ll}
\hline Name & \multicolumn{1}{c}{ Sequence (5' to $\mathbf{3}^{\prime}$ ) } \\
\hline VH1L & TCACCATGGACTGGACCTGGAG \\
VH2L & ACCATGGACATACTTTGTTCACGC \\
VH2L.2 & ACCATGGACACACTTTGCTCCACGC \\
VH3L & ACCATGGAGTTTGGGCTGAGCTG \\
VH3L.2 & ACCATGGAACTTGGGCTCCGCTG \\
VH4L & AAGAACATGAAACACCTGTGGTTCTTC \\
VH5L & ATCATGGGGTCAACCGCCATCCT \\
VH6L & ACAATGTCTGTCTCCTTCCTCATC \\
\hline
\end{tabular}

${ }^{a}$ Oligonucleotides VH2L and VH2L.2 as well as VH3L and VH3L.2 were used as a 1:1 mixture, respectively. The $V_{H}$ oligonucleotides hybridize to the leader region of the respective $\mathrm{V}_{\mathrm{H}}$ gene family.

genes or not remains an open question. Since nearly all human $V_{\kappa}$ genes have been ordered and sequenced (31), a sequence analysis of rearranged $V_{\kappa}$ genes represents a reliable approach to study somatic mutation in antibody genes of BL.

In the present work $10 \kappa$-expressing BL cell lines of sporadic and endemic origin and three $\boldsymbol{\kappa}$-expressing endemic BL biopsy specimens were analyzed for somatic mutation in their rearranged $\mathrm{V}$ region genes. It turned out that all cell lines and tumors harbor somatically mutated $\mathrm{V}$ region genes, indicating that they originate from GC or GC-derived B cells.

\section{MATERIALS AND METHODS}

\section{Amplification of Rearranged $V_{H}$ and $V_{\kappa}$ Region Genes by Reverse Transcriptase PCR}

RNA was isolated from 10 Burkitt's lymphomaderived cell lines as described (32). For first strand cDNA synthesis total cellular RNA of $5 \times$ $10^{4}$ cells was hybridized to oligonucleotides recognizing the first exon of the $\mathrm{C} \kappa(\mathrm{C} \kappa[15])$ and either the $C \mu$ or a $C \gamma$ constant region genes (16) and extended using SuperScript MMLV reverse transcriptase II (Gibco-BRL, Gaithersburg, MD, U.S.A.). Amplification of $V_{H}$ gene rearrangements was performed with a set of $\mathrm{VH}$ leader family-specific primers (Table l) together with a $\mathrm{C} \mu$ or a $\mathrm{C} \gamma$ primer (see Ref. 16) in separate 
reactions for each $\mathrm{V}_{\mathrm{H}}$ gene family. The PCR mixtures contained $1 / 20$ of the cDNA mixture, 200 $\mu \mathrm{M}$ each dNTP, $10 \mathrm{mM}$ Tris- $\mathrm{HCl} \mathrm{pH} 8.4,1.5 \mathrm{mM}$ $\mathrm{MgCl}_{2}\left(2.5 \mathrm{mM}\right.$ for the $\mathrm{V}_{\mathrm{H}} 4 \mathrm{~L}$ primer) $50 \mathrm{mM}$ $\mathrm{KCl}, 0.125 \mu \mathrm{M}$ of one of the $\mathrm{V}_{\mathrm{H}}$ primers, 0.125 $\mu \mathrm{M}$ of the $\mathrm{C} \mu$ or $\mathrm{C} \gamma$ primers, and 1.25 units of Taq DNA polymerase. Cycling conditions were: $95^{\circ} \mathrm{C} 2 \mathrm{~min}, 65^{\circ} \mathrm{C} 4 \mathrm{~min}, 72^{\circ} \mathrm{C} 1 \mathrm{~min}$, followed by $95^{\circ} \mathrm{C} 60 \mathrm{sec}, 61^{\circ} \mathrm{C} 30 \mathrm{sec}, 72^{\circ} \mathrm{C} 60 \mathrm{sec}$ for 34 cycles; and finally an incubation step at $72^{\circ} \mathrm{C}$ for 5 min. Taq DNA polymerase was added after the first denaturation step.

Amplification of $V_{\kappa}$ gene rearrangements was performed with a set of $V_{\kappa}$ gene familyspecific primers (hybridizing to framework region I of $\mathrm{V}_{\kappa}$ families $1-4 ; \mathrm{V}_{\kappa} 1,2,4$ see Ref. 18; $\mathrm{V}_{\kappa}$ 3: 5'TTGTG $\langle$ AT $\rangle$ TGAC $\langle$ AG $\rangle$ CAGTCTCCAG $\langle$ GC $\rangle$ $\mathrm{CACC}^{\prime}$ ) together with a $\mathrm{C}_{\kappa}$ primer (see Ref. 15) in separate reactions for each of the $V_{\kappa} 1$ to $V_{\kappa} 4$ gene families. The PCR reaction mixtures and the cycling conditions were as described above except that the annealing temperature was set to $63^{\circ} \mathrm{C}$.

\section{Amplification of Rearranged $V_{\kappa}$ Region Genes from Genomic DNA}

DNA was isolated from frozen biopsy specimens of three cases of $\kappa$-expressing Burkitt's lymphoma by standard methods (33). $V_{\kappa}$ region genes were amplified from $100 \mathrm{ng}$ of genomic DNA with a set of four $V_{\kappa}$ family-specific primers (see above) and a $J_{\kappa}$ primer mix ( $3^{\prime} \operatorname{mix}[18]$ ) in separate reactions for each of the $\mathrm{V}$ gene primers. The PCR reaction mixtures and the cycling conditions were as described above, using $2.5 \mathrm{mM}$ $\mathrm{MgCl}_{2}$ and $61^{\circ} \mathrm{C}$ as annealing temperature.

\section{Amplification of the B3 Germline Gene from Patient MM}

The B3 germline gene was amplified from genomic DNA of the tumor specimen of patient $M M$ with the $V_{\kappa} 4$ FRI primer (see above) and a primer hybridizing to the recombination signal sequence of the $B 3$ germline gene (B3Rev: 5'AGGAGGTTTGTGTTCGAGGCTGAAG3'). The reaction mix contained in $50 \mu \mathrm{l}$ : $50 \mathrm{ng}$ of genomic DNA, $200 \mathrm{mM}$ each dNTP, $10 \mathrm{mM}$ Tris$\mathrm{HCl} \mathrm{pH} \mathrm{8.4,} \mathrm{1,5} \mathrm{mM} \mathrm{MgCl}, 50 \mathrm{mM} \mathrm{KCl}, 0.125$ $\mu \mathrm{M}$ of primer VK4 and B3Rev, and 1.25 units Taq DNA polymerase. Cycling conditions were: $95^{\circ} \mathrm{C} 5 \mathrm{~min}, 63^{\circ} \mathrm{C} 4 \mathrm{~min}, 72^{\circ} \mathrm{C} 60 \mathrm{sec}$; followed by $95^{\circ} \mathrm{C} 60 \mathrm{sec}, 63^{\circ} \mathrm{C} 30 \mathrm{sec}, 72^{\circ} \mathrm{C} 60 \mathrm{sec}$ for 34 cycles. The reaction ended with a 5 -min incuba- tion at $72^{\circ} \mathrm{C}$. Enzyme was added after the first denaturation step.

\section{Sequence Analysis of PCR Products}

PCR products were gel-purified and directly sequenced without subcloning. Sequence reactions were performed either with ${ }^{32} \mathrm{P}$-labeled oligonucleotides or with Digoxigenin-labeled primers, using the GATC direct blotting system (MWG Biotech, Ebersberg, Germany) and the Dig Taq Sequencing Kit (Boehringer-Mannheim, Mannheim, Germany) in the latter case. The $\mathrm{V}$ gene sequences have been submitted to the EMBL Data Library under accession numbers X87437 X8746.

\section{RESULTS}

\section{$V_{\kappa}$ and $V_{H}$ Gene Rearrangements of 10 Burkitt's Lymphoma-Derived Cell Lines}

$V_{\kappa}$ and $V_{H}$ region genes were amplified from cDNA generated from $10 \kappa$-expressing BL lines. Seven of the lines were derived from sporadic cases of BL, two from endemic cases and one from a North African case which is related to the sporadic form of BL (Table 2). The BL line of North African origin, as well as both lines derived from endemic and two of the lines derived from the sporadic cases are EBV-positive (Table 2).

From 9 of the $10 \kappa$-expressing BL, one potentially functional $V_{\kappa}$ gene rearrangement was obtained (Table 2, Fig. 1). Two potentially functional $V_{\kappa}$ rearrangements were amplified from cell line BL41 (Table 2, Fig. 1). Products were obtained for each of the $V_{\kappa}$ gene families 1-4. The $V_{\kappa} 4$ gene $B 3$ was found to be rearranged three times, the $V_{\kappa} 1$ gene 02 , the $V_{\kappa} 2$ gene A3, and the $V_{\kappa} 3$ genes L2 and A27 were each rearranged in two cell lines. The $\mathrm{V}_{\kappa} 3$ gene rearrangement of BL41 harbors a deletion of three nucleotides in complementarity determining region (CDR) I (Fig. 1). This should not interfere with the expression of a functional light chain, since sequence length variation is frequently found in CDRs of $V_{H}$ and $V_{\kappa}$ germline genes $(31,34)$. The detection of two potentially functional $V_{\kappa}$ gene rearrangements appears to violate the principle of L chain isotype exclusion. However, since not the entire $\mathrm{V}$ gene sequences were determined, it is possible that only one of the two $V_{\kappa}$ gene rearrangements is functional and can be translated into protein. Indeed, BL41 has been de- 
TABLE 2. $V_{H}$ and $V_{\kappa}$ region gene sequence analysis of 10 Burkitt's lymphoma cell lines

\begin{tabular}{|c|c|c|c|c|c|c|c|c|c|c|}
\hline $\begin{array}{l}\text { Burkitt } \\
\text { Line }\end{array}$ & Class & Origin $^{a}$ & $\underset{\text { Family }}{\mathbf{V}_{\mathbf{H}}}$ & $\begin{array}{l}V_{H^{b}}^{b} \\
\text { Gene }\end{array}$ & $\begin{array}{l}\text { Mutations/bp } \\
\text { Sequenced }^{c}\end{array}$ & $\begin{array}{c}\% \\
\text { Mutation }\end{array}$ & $\underset{\mathbf{N}_{\boldsymbol{\kappa}}}{\text { Family }}$ & $\begin{array}{l}V_{\kappa}^{b} \\
\text { Gene }\end{array}$ & $\begin{array}{l}\text { Mutations/bp } \\
\text { Sequenced }^{c}\end{array}$ & $\begin{array}{c}\% \\
\text { Mutation }\end{array}$ \\
\hline Jijoye $\mathrm{P} 79^{d}$ & $\mu$ & $\mathrm{e}$ & & & & & 3 & $\mathrm{~L} 2$ & $15 / 292$ & 5.1 \\
\hline Daudi $^{d}$ & $\mu$ & $\mathrm{e}$ & 3 & Hll & $52 / 337$ & 15.0 & 1 & $\mathrm{O} 2$ & $29 / 288$ & 10.1 \\
\hline $\mathrm{BL} 36^{d}$ & $\gamma$ & $s$ & 3 & DP58 & $19 / 337$ & 5.6 & 3 & $\mathrm{~L} 2$ & $5 / 297$ & 1.7 \\
\hline \multirow[t]{2}{*}{$\mathrm{BL} 29^{d}$} & $\mu$ & s & 4 & VH4.21 & $2 / 332$ & 0.6 & 4 & B3 & $10 / 294$ & 3.4 \\
\hline & & & 2 & $S 12-9^{e}$ & $18 / 347$ & 5.2 & & & & \\
\hline $\mathrm{JI}^{d}$ & $\mu$ & $\mathrm{s}$ & 3 & LSG 10.1 & $8 / 343$ & 2.3 & 4 & B3 & $4 / 294$ & 1.4 \\
\hline \multirow[t]{2}{*}{ BL4l } & $\mu$ & s & 3 & 1-9III & $14 / 338$ & 4.1 & 3 & $\mathrm{~A} 27^{f}$ & $13 / 294$ & 4.4 \\
\hline & & & & & & & 4 & B3 & $0 / 286$ & 0.0 \\
\hline CA46 & $\mu$ & s & 5 & BLK & $1 / 333$ & 0.3 & 3 & $\mathrm{~A} 27$ & $3 / 297$ & 1.0 \\
\hline ST486 & $\mu$ & s & 3 & I-9III & $13 / 326$ & 4.0 & 2 & A3 & $4 / 295$ & 1.4 \\
\hline CW698 & $\mu$ & s & 3 & DP51 & $15 / 341^{g}$ & 4.4 & 1 & $\mathrm{O} 2$ & $6 / 299$ & 2.0 \\
\hline BL31 & $\mu$ & s & 4 & VH4.21 & $14 / 327$ & 4.3 & 2 & A3 & $2 / 297$ & 0.7 \\
\hline
\end{tabular}

${ }^{a}$ The origin of the lines is indicated (e, endemic; s, sporadic).

${ }^{b}$ References for $V_{H}$ germline genes: DP51, DP58 (34), H1 1 (35), VH4.21, BLK (36), S12-9 (37), LSG10.1 (38), 1-9III (39). References for $V_{\kappa}$ germline genes are summarized by Schäble 8 Zachau (31).

'The number of basepairs sequenced represents the sum of the $\mathrm{V}$ and $\mathrm{J}$ segments, excluding $\mathrm{D}_{\mathrm{H}}$ genes and $\mathrm{N}$ nucleotides.

${ }^{d} \mathrm{EBV}$ positive lines.

${ }^{e}$ deletion of eight nucleotides in FRI.

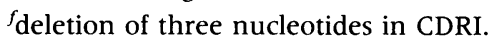

${ }^{g}$ insertion of three nucleotides in CDRII.

scribed to produce only one light chain with a $\mathrm{V}$ gene segment belonging to the $V_{\kappa} 3$ family (21).

Potentially functional $\mathrm{V}_{\mathrm{H}}$ gene rearrangements were obtained from 9 of the 10 BL lines. Rearrangements of $\mathrm{V}_{\mathrm{H}}$ gene families 2-5 were obtained, six of which could be assigned to the $\mathrm{V}_{\mathrm{H}} 3$ family. No $\mathrm{V}_{\mathrm{H}}$ gene rearrangement could be amplified from cell line Jijoye P79 using either $\mathrm{V}_{\mathrm{H}}$ leader or framework region (FR) I primers (not shown). An attempt to amplify the $\mathrm{V}_{\mathrm{H}}$ gene rearrangement from this line using genomic DNA also failed. This may be due either to the occurrence of somatic mutations preventing successful amplification, to the usage of a hithero unknown $\mathrm{V}_{\mathrm{H}}$ gene or to structural aberrations in the $\mathrm{V}_{\mathrm{H}}$ gene. Production of a truncated heavy chain has indeed been described for another Jijoye-subline (41). From cell line BL29 two $V_{H}$ gene rearrangements were obtained in the RNA analysis: a potentially functional $\mathrm{V}_{\mathrm{H}} 4.21$, and a nonfunctional $\mathrm{V}_{\mathrm{H}} 2$ gene rearrangement carrying a deletion of eight nucleotides in FR I. The $\mathrm{V}_{\mathrm{H}} 2$ gene used in this rearrangement shows highest homology to the S12-9 gene (Table 2). Finally, in BL line CW698 a deletion of three basepairs was found within CDRII of the $\mathrm{V}_{\mathrm{H}} 3$ gene rearrangement.

\section{Somatic Mutations in $\mathbf{V}$ Region Genes of BL Lines}

The analysis of the ten BL lines for somatic mutation in their rearranged $V$ region genes is summarized in Table 2 . Somatic mutations were found in all lines. Interestingly, there was a clear difference in terms of mutational load between $V_{\kappa}$ genes derived from endemic versus sporadic $\mathrm{BL}$ cases. While the $\mathrm{V}_{\kappa}$ genes of the two endemic cell lines Daudi and Jijoye P79 showed mutation frequencies of $10.1 \%$ and $5.1 \%$, respectively (29 and 15 basepair differences), the average mutation frequency in the eight sporadic cases was $1.8 \%$ (range $0-13$ point mutations).

Nucleotide differences to the putative germline genes were also detected in each of the $10 \mathrm{~V}_{\mathrm{H}}$ gene rearrangements (Table 2). However, since $\mathrm{V}_{\mathrm{H}}$ gene polymorphism may account for some of 


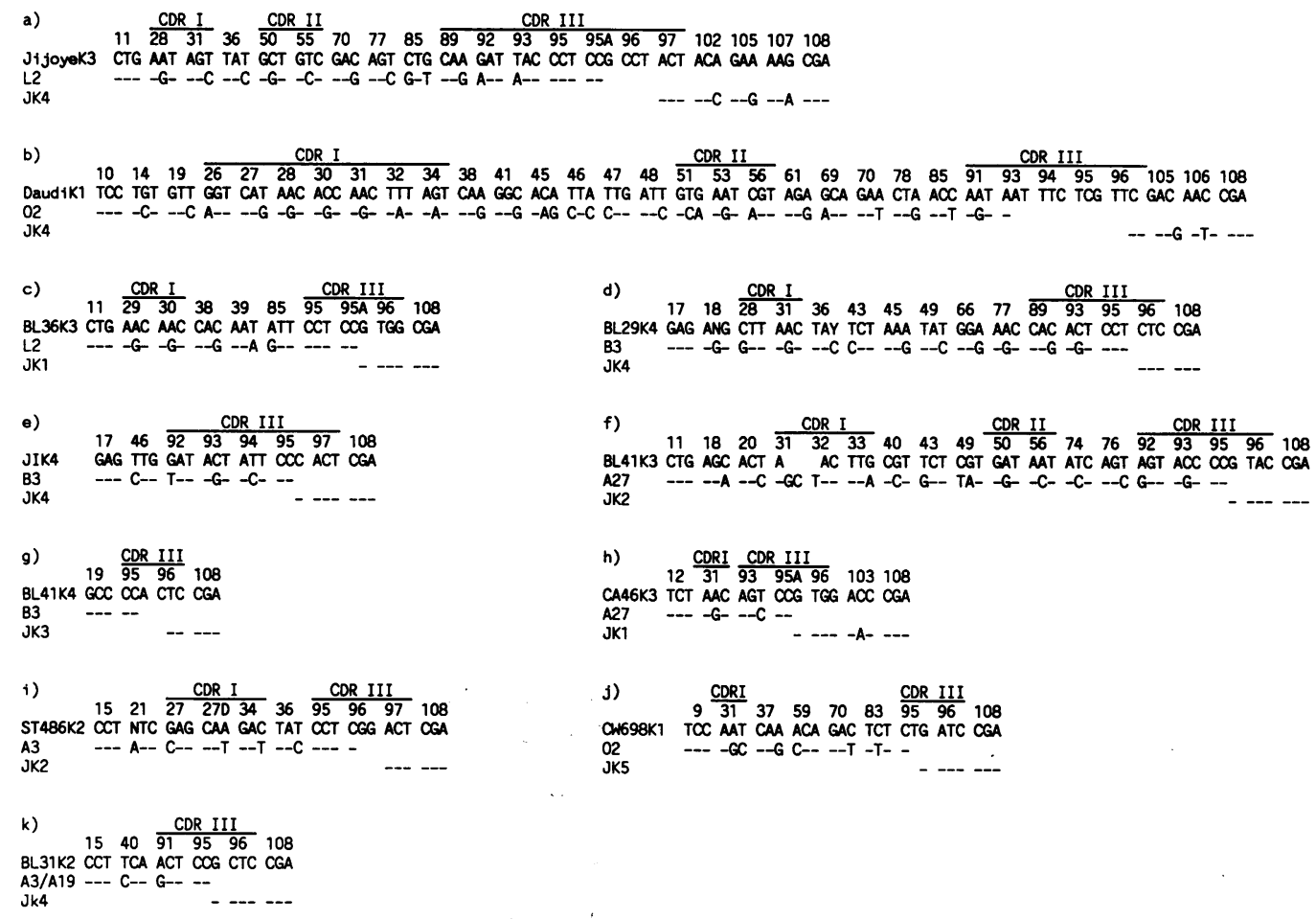

FIG. 1. $V_{\kappa}$ gene sequences of $10 \mathrm{BL}$ lines

$\mathrm{V}_{\kappa}$ region gene sequences are compared with the most homologous germline genes. Dashes indicate sequence identity. Only the first and last codons of the sequences and those codons of the $V_{\kappa}$ and $J_{\kappa}$ genes that differ from the respective germline genes are shown. For references for $V_{\kappa}$ germline genes, see Schäble and Zachau (31), $J_{\kappa}$ sequences are from Hieter et al. (40). The aminoacid code and the codon numbers are given above the sequence. CDR I-III are indicated. a) JijoyeK3, b) DaudiKl, c) BL36K3, d) BL29K4, e) JIK4, f) BL41K3, g) BL4lK4, h) CA46K3, i) ST486K2, j) CW698K1, k) BL31K2.

the nucleotide differences between the putative germline genes and the rearranged $\mathrm{V}_{\mathrm{H}}$ genes, an unequivocal identification of somatic mutation is not in all cases possible. In particular, sequence polymorphism is common in the $\mathrm{V}_{\mathrm{H}} 3$ gene family (38). Members of this family were involved in 6 of the $10 \mathrm{~V}_{\mathrm{H}}$ gene rearrangements (Table 2).

Three lines for which the $V_{\kappa}$ genes had already been sequenced several years ago were included in the analysis. From the sporadic lines JI and BL4l, sequences identical to those previously published $(21,22)$ were determined in the present study. On the other hand, the $\mathrm{V}_{\kappa} 1$ sequence which we obtained from the endemic Daudi line differed by three point mutations from the sequence published by Klobeck et al. (20). Interestingly, another group recently reported a $V_{H} 3$ sequence from the Daudi line that differed from that determined in the present work by 14 point mutations (EMBL accession number HS07987).

\section{$V_{\kappa}$ Gene Sequence Analysis of Three Cases of Endemic Burkitt's Lymphoma}

$\mathrm{V}_{\kappa}$ gene rearrangements were amplified from three cases of $\kappa$-expressing endemic BL using genomic DNA isolated from biopsy material. From each of the cases one PCR product was obtained. Cases JN and KD use $\mathrm{V}_{\kappa} 1$ genes with highest homology to the $\mathrm{Ll}$ and Lll germline genes, respectively $(5.0 \%$ mutation, or $13 \mathrm{bp}$ differences, in both cases; Table 3, Fig. 2). A $\mathrm{V}_{\kappa} 4$ gene rearrangement harboring $14 \mathrm{bp}$ differences ( $5.5 \%$ mutation) relative to the $\mathrm{V}_{\kappa} 4$ germline gene B3 was amplified from case MM (Table 3, Fig. 2). To exclude that some of the nucleotide differences in the $\mathrm{V}$ region genes are due to $\mathrm{V}$ gene polymorphism in patients of African origin, the $\mathrm{V}_{\kappa} 4$ germline gene was amplified and directly sequenced from the biopsy material of patient MM (see Materials and Methods). A sequence identical to the published B3 sequence was obtained (not shown). This sequence should repre- 


\begin{tabular}{|c|c|c|c|}
\hline $\begin{array}{l}\text { Burkitt } \\
\text { Case }\end{array}$ & $\begin{array}{c}\mathbf{V}_{\kappa} \\
\text { Family }\end{array}$ & $\begin{array}{l}V_{\kappa} \\
\text { Gene }\end{array}$ & $\begin{array}{c}\% \\
\text { Mutation }\end{array}$ \\
\hline JN & 1 & Ll & 5.0 \\
\hline KD & 1 & Ll1 & 5.0 \\
\hline MM & 4 & B3 & 5.5 \\
\hline
\end{tabular}

For references of $\mathrm{V}_{\kappa}$ germline genes, see Schäble \& Zachau (31).

sent a mixture of the $\mathrm{V}_{\kappa} 4$ sequences from both alleles, which-since a cleary readable sequence was obtained-appear to be identical in patient MM. However, since the fraction of tumor cells in the specimen of patient MM is not known, it cannot be formally excluded that the amplified sequence represents the $\mathrm{B} 3$ sequence of the second allele in the tumor cells, if this has not been deleted during rearrangement. Nevertheless, the fact that a sequence identical to the one repeatedly sequenced from Caucasians was obtained supports the assumption that $\mathrm{V}_{\kappa}$ gene polymorphism does not represent a serious problem in the analysis of $V_{\kappa}$ genes for somatic mutation (42).

\section{Replacement Versus Silent Mutation (R/S) Analysis}

Taking into account all point mutations in both the BL lines and biopsies analyzed in the present work, the resulting R/S values are 3.8 (23/6) and

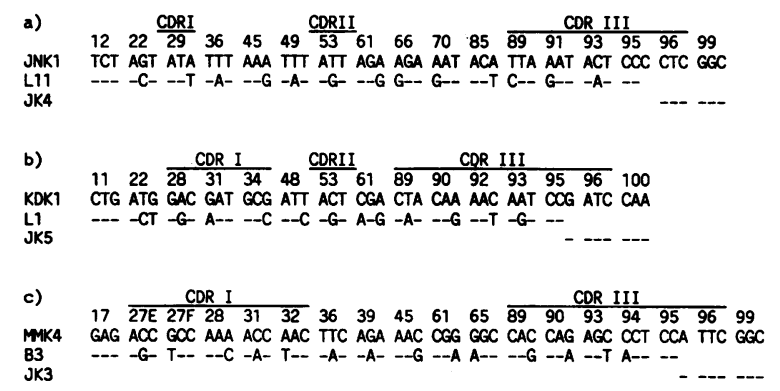

FIG. 2. $V_{\kappa}$ gene sequences of three cases of endemic $B L$

The sequence format is as in Fig. 1. a) JNK1, b) KDK1, c) MMK4.
$9.0(9 / 1)$ for CDRI and CDRII, respectively, and $1.0(15 / 15)$ and $1.0(13 / 13)$ for FRII and FRIII, respectively. For $\mathrm{V}_{\kappa} 3$ genes the calculated R/S values assuming random mutagenesis are 4.3 and 2.5 for CDRI and CDRII, respectively, and 3.8 and 3.4 for FRII and FRIII, respectively. The counterselection of replacement mutations in the FR indicates that these tumors were selected for the preservation of a functional antibody structure. However, it should be noted that some BL lines produce no functional antibody protein $(19,43,44)$.

\section{DISCUSSION}

\section{Unusual Patterns of Ig Gene Rearrangement and Expression in $\mathrm{BL}$}

In the past, several cases of BL producing heavy chain proteins of abnormal size have been described $(19,41,43,44)$. Such cell lines produce shortened heavy chains due to usage of alternate splice sites within the $V_{H}$ gene. Furthermore, deletions and insertions were found in the heavy and light chain $\mathrm{V}$ genes $(19,41,43,44)$. We also found in the present collection of $\mathrm{BL}$, although the tumor cells appeared normal, unusual patterns of Ig gene rearrangements and expression. Thus, BL29H2 harbored a deletion of 8 nucleotides in FRI, CW698H3 carried a three basepair deletion in CDRII, and an insertion of three nucleotides was found in BL41K3. Although it cannot be ruled out that those $\mathrm{V}$ genes represent rare polymorphic forms of the corresponding germline genes, we consider it more likely that the deletions and insertions occurred somatically within the tumor B cells or their precursors. Taking into account that only the expressed $\mathrm{V}$ region genes were analyzed in the present study (with the exception of BL29H2 and BL41K4, see below) the occurrence of abnormal rearrangements in BL may be even higher than suggested by the mRNA-based analysis.

Other surprising findings in the present analysis was the detection of both a functional and a nonfunctional heavy chain transcript in BL29, and of two potentially functional $\kappa$ light chain transcripts in BL41. Usually, a peripheral B cell carries only one functional heavy and light chain gene rearrangement, and stable mRNA is produced only from the functional gene rearrangements (45). A possible explanation for the expression of both $\mathrm{V}_{\mathrm{H}}$ gene rearrangements in BL29 may lie in the fact that a translocation of 
TABLE 4. Summary of mutations in BL and various B cell subsets

\begin{tabular}{lcccc}
\hline Cell Population & $n^{a}$ & Range & $\begin{array}{c}\% \\
\text { Mutation }\end{array}$ & Reference \\
\hline Endemic Burkitt & 5 & $13-29$ & 6.0 & Present Work \\
Sporadic Burkitt & 7 & $0-13$ & 1.8 & Present Work \\
$\mu^{+} \delta^{+}$PBL & 16 & $0-3$ & 0.2 & $15 ;^{b}$ \\
$\mu$-Only PBL & 28 & $0-13$ & 1.9 & $15 ;^{b}$ \\
Class-Switched PBL & 12 & $3-23$ & 4.0 & $15 ;^{b}$ \\
$\mu$-Expressing GCC & 8 & $1-10$ & 2.0 & 16 \\
Class-Switched GCC & 9 & $1-13$ & 3.3 & 16 \\
\hline
\end{tabular}

$a_{n}$, number of sequences.

${ }^{b} \mathrm{U}$. Klein, R. Küppers, and K. Rajewsky, submitted for publication.

the c-myc oncogene into the IgH locus has occurred in this cell line (46). This translocation, which put the c-myc gene into one of the $\mathrm{Ig}$ switch regions downstream of $\mathrm{C} \mu$ of the nonfunctional $V_{H}$ gene rearrangement, may have caused a higher rate of transcription of this heavy chain gene.

Since BL41 has been shown to express only the $V_{\kappa} 3$ light chain protein on its cell surface (21) it seems likely that the mRNA of the $V_{\kappa} 4$ rearrangement is not translated into protein. This might be due, for example, to mutations in parts of the gene that were not covered by our sequence analysis.

\section{Different Patterns of Somatic Mutation in Endemic and Sporadic BL}

The developmental status of an individual B cell can be determined through the expression of the various Ig heavy chain classes and stage-specific cell surface markers, and most notably the level of somatic mutation in its rearranged $\mathrm{V}$ region genes $(11,15-17,47,48)$. Thus, newly arising $B$ cells in the bone marrow are released into the periphery as $\operatorname{IgM}^{+} \operatorname{IgD}^{+} \mathrm{B}$ cells carrying unmutated Ig gene rearrangements. These cells are considered to be precursors of antigen-activated $B$ cells which proliferate and hypermutate their $\mathrm{V}$ genes in the GC microenvironment to generate affinity-increased antibodies (18). Eventually, selected B cells leave the GC as either somatically mutated class switched memory B cells or plasma cells (47).

Recently, the existence of another major hu- man B cell subset harboring somatically mutated $\mathrm{V}$ region genes has become evident (Ref. 15 and U. Klein, R. Küppers, and K. Rajewsky, submitted for publication). About $10 \%$ of peripheral blood B cells are surface IgM-positive/IgD-negative and show a mutation frequency in their $\mathrm{V}$ region genes ( $1.9 \%$; Table 4$)$ that is half of that characteristic for class-switched peripheral blood B cells $(4.0 \%$; Table 4$)$. These IgM-only B cells phenotypically resemble classical $\operatorname{IgM}^{-} \mathrm{IgD}^{-}$ memory B cells in several respects: they are $\mathrm{CD}_{23}{ }^{-}$, resting, and have elevated $\kappa$ light chain mRNA levels compared with $\operatorname{IgM}^{+} \operatorname{IgD}^{+}$B cells (U. Klein, R. Küppers, and K. Rajewsky, submitted for publication). This suggests that these cells represent IgM-expressing memory B cells which have been selected in the microenvironment of the GC during $\mathrm{T}$ cell-dependent antibody responses. Alternatively however, IgM-only B cells might be generated in a GC-independent pathway. Somatic hypermutation in the absence of external antigens is used in the sheep to diversify the primary antibody repertoire (49). This process takes place within the ileal Peyer's patches (50). In the human, there is as yet no evidence for such a B cell-developmental pathway.

To study Burkitt's lymphoma for somatic mutation of IgV genes, we focused on the expressed $\kappa$ light chain genes of cell lines and biopsy specimens from sporadic and endemic BL cases. Virtually all human $V_{\kappa}$ genes are now known (31) and seem to exhibit little sequence polymorphism, thus representing ideal substrates for a reliable analysis of somatic mutation in peripheral B cell subsets $(15,51)$. Somatic 
point mutations were identified in each of the 13 samples. Interestingly, comparing the level of somatic mutation in sporadic $(n=8)$ versus endemic ( $n=5)$ cases, a considerably higher number of point mutations per $\mathrm{V}$ gene was evident in endemic BL which is confined to African patients. That the higher mutation frequency in endemic versus sporadic cases is not due to $V_{\kappa}$ gene polymorphism in Africans is strongly indicated by the fact that $\mathrm{a} \mathrm{V}_{\kappa} 4$ gene sequence identical to that found in Caucasians was amplified from the genomic DNA of patient MM.

\section{The Level of Somatic Mutation in Sporadic BL Suggests a Relation to IgM- Only Cells of the GC and the Peripheral Blood}

The number of point mutations in the $\kappa$ light chains of the sporadic BL lines ranged from 0 to 13 with a mean somatic mutation frequency of $1.8 \%$. Both the range of mutations per $\mathrm{V}$ gene and the mutation frequency are strikingly similar to those found in two human IgM-expressing peripheral B cell subsets, namely $\mu$ chain-positive GC B cells $(1-10 ; 2.0 \%)$ and IgM-only peripheral blood B cells $(0-13 ; 1.9 \%)$ (Table 4$)$. On the contrary, the corresponding class-switched GC and peripheral blood B cells show considerably higher mutation frequencies $(3.3 \%$ and $4.0 \%$, respectively; Table 4$)(15-17)$. This observation, together with the fact that most sporadic BLs are IgM-positive/IgD-negative (1; 7/8 sporadic $\mathrm{BL}$ lines studied in the present work show this phenotype), clearly indicates a relation of sporadic BL to somatically mutated IgM-expressing B cells. The surface expression of the GCassociated markers CD10, CD38, and CD77 on most BL cases $(5,6)$ suggests that the tumor $B$ cells of BL are derived from GC B cells. On the other hand, a possible relation to IgM-only B cells in the periphery (Ref. 15 and U. Klein, R. Küppers, and K. Rajewsky, submitted for publication) is suggested by the extra-nodal appearance of BL. As discussed in the previous section, such IgM-only cells probably represent GC-derived memory $B$ cells. Thus, the phenotypic resemblance of the tumor cells with GC B cells, together with the extra-nodal location of $\mathrm{BL}$, indicates a derivation of the tumor cells in sporadic $B L$ from a $B$ lymphocyte which is at the transition from the GC to the IgM memory B cell compartment. The extra-lymphatic location and the apparent absence of ongoing IgV gene mutation in sporadic BL (27) clearly distinguish those tumors from the well-characterized GC B cell-malignancy follicular lymphoma $(52,53)$.

\section{Endemic BL Carry V Region Genes with a Higher Load of Somatic Mutation Than Sporadic BL}

The five endemic BL cases harbored between 13 and 29 point mutations in their rearranged $V_{\kappa}$ genes, yielding a mean somatic mutation frequency of $6.0 \%$. These observations are supported by results recently obtained by Chapman et al. (54), who also found $V$ genes expressed in endemic BL lines to be highly diversified by somatic mutation. The significant higher load of mutations in the endemic versus the sporadic cases suggests that these BL subtypes differ in the developmental stage of the $B$ cell that gave rise to the malignant clone. This is further supported by the finding that sporadic and endemic BL show distinct patterns of c-myc translocations (3). Interestingly, the B cell-immortalizing EpsteinBarr virus is found in essentially all cases of endemic BL. Perhaps the presence of this virus in a GC B cell alters the way how these cells are selected and/or proliferate within the GC, resulting in the acquisition of a high load of somatic point mutations. Still, endemic BL phenotypically resembles sporadic $\mathrm{BL}$, also in that most cases are surface IgM-positive/IgD-negative (1). This is surprising since both within the GC and the memory B cell fractions, B lymphocytes carrying highly diversified $\mathrm{V}$ genes predominantly express other isotypes (16,17; see also Table 4). The observation that the Daudi cell line seems to mutate in vitro points to an alternative explanation for the higher somatic mutation frequency-in the absence of class switch-in endemic BL cases: the transformed B cell clone continues to diversify somatically its rearranged $\mathrm{V}$ genes during extra-nodal tumor growth, and being removed from the GC-microenvironment, the malignant clone would not receive the necessary signals for class switching. Interestingly, also Chapman et al. found evidence for intraclonal heterogeneity in one of the endemic BL lines analysed (54). This heterogeneity is most likely due to ongoing somatic mutation in the tumor cells in vivo (54).

In conclusion, the present results show that classical BL represent lymphomas originating from mature $B$ cells expressing $V$ region genes diversified by somatic mutation. More specifically, their phenotypic resemblance to GC B cells, in conjunction with the extra-nodal location, 
suggests that $\mathrm{BL}$ is a $\mathrm{B}$ cell malignancy originating from GC or GC-derived B cells. The considerable difference between the somatic mutation frequencies of sporadic and endemic BL indicates that these two subtypes of classical BL differ with respect to the developmental status of the cell that upon malignant transformation gave rise to the BL-tumor.

\section{ACKNOWLEDGMENTS}

This work was supported by Deutsche Forschungsgemeinschaft through Dil84 and SFB 242. We thank H. G. Zachau for helpful discussions and $\mathrm{H}$. Gustav Klobeck for critical reading of the manuscript.

\section{REFERENCES}

1. Magrath I. (1990) The pathogenesis of Burkitt's lymphoma. Adv. Cancer Res. 55: 133260.

2. Klein G, Klein E. (1985) Evolution of tumours and the impact of molecular oncology. Nature 315: 190-195.

3. Shiramizu B, Barriga F, Neequaye J, et al. (1991) Patterns of chromosomal breakpoint locations in Burkitt's lymphoma: Relevance to geography and Epstein-Barr virus association. Blood 77: 1516-1526.

4. Harris NL, Jaffe ES, Stein H, et al. (1994) A revised European-American classification of lymphoid neoplasms: A proposal from the international lymphoma study group. Blood 84: 1361-1392.

5. Ling NR, Hardie D, Lowe J, Johnson GD, Khan M, MacLennan ICM. (1989) A phenotypic study of cells from Burkitt lymphoma and EBV-B-lymphoblastoid lines and their relationship to cells in normal lymphoid tissues. Int. J. Cancer 43: 112-118.

6. Gregory CD, Tursz T, Edards CF, et al. (1987) Identification of a subset of normal $\mathrm{B}$ cells with a Burkitt's lymphoma (BL-)-like phenotype. J. Immunol. 139: 313-318.

7. Kraal G, Weissman IL, Butcher EC. (1982) Germinal centre B cells: Antigen specificity and changes in heavy chain class expression. Nature 298: 377-379.

8. Feuillard J, Taylor D, Casamayor-Palleja M, Johnson GD, MacLennan ICM. (1995) Isolation and characteristics of tonsil centroblasts with reference to Ig class switching. Intern. Immunol. 7: 121-130.

9. Snapper CM, Mond JJ. (1993) Toward a comprehensive view of immunoglobulin class switching. Immunol. Today 14: 15-17.

10. Klein G. (1987) In defense of the "old" Burkitt lymphoma scenario. Adv. Viral Oncol. 7: 207-211.

11. Stewart AK, Schwartz RS. (1994) Immunoglobulin $\mathrm{V}$ regions and the $\mathrm{B}$ cell. Blood 83: 1717-1730.

12. Greaves MF, Hariri G, Newman RA, Sutherland DR, Ritter MA, Ritz J. (1983) Selective expression of the common acute lymphoblastic leukemia (gpl00) antigen on immature lymphoid cells and their malignant counterparts. Blood 61: 628-639.

13. Tedder TF, Clement LT, Cooper MD. (1984) Discontinuous expression of a membrane antigen (HB-7) during B lymphocyte differentiation. Tissue Antigens 24: 140-149.

14. Schittek B, Rajewsky K. (1992) Natural occurrence and origin of somatically mutated memory B cells in mice. J. Exp. Med. 176: 427-438.

15. Klein U, Küppers R, Rajewsky K. (1993) Human IgM + IgD $+B$ cells, the major $B$ cell subset in the peripheral blood, express $V \kappa$ genes with no or little somatic mutation throughout life. Eur. J. Immunol. 23: 32723277.

16. Klein U, Küppers R, Rajewsky K. (1994) Variable region gene analysis of $\mathrm{B}$ cell subsets derived from a 4-year-old child: Somatically mutated memory B cells accumulate in the peripheral blood already at young age. $J$. Exp. Med. 180: 1383-1393.

17. Pascual V, Liu YJ, Magalski A, de Bouteiller O, Banchereau J, Capra JD. (1994) Analysis of somatic mutation in five B cell subsets of human tonsil. J. Exp. Med. 180: 329-339.

18. Küppers R, Zhao M, Hansmann ML, Rajewsky K. (1993) Tracing B cell development in human germinal centres by molecular analysis of single cells picked from histological sections. E.M.B.O. J. 12: 4955-4967.

19. Mounir S, Guglielmi P, Preud'Homme JL, Nau F, Cogne M. (1990) Alternate splice sites within the human $\mathrm{VH}$ gene coding sequences lead to truncated Ig $\mu$-chains. J. Immunol. 144: 342-347.

20. Klobeck HG, Combriato G, Zachau HG. (1984) Immunoglobulin genes of the $\kappa$ light chain type from two human lymphoid cell 
lines are closely related. Nucleic Acids Res. 12: 6995-7006.

21. Klobeck HG, Meindl A, Combriato G, Solomon A, Zachau HG. (1985) Human immunoglobulin kappa light chain genes of subgroup II and III. Nucleic Acids Res. 13: 64996513.

22. Klobeck HG, Bornkamm GW, Combriato G, Mocikat R, Pohlenz HD, Zachau HG. (1985) Subgroup IV of human immunoglobulin $\kappa$ light chains is encoded by a single germline gene. Nucleic Acids Res. 13: 6515-6529.

23. Kato S, Tachibana K, Takayama N, Kataoka H, Yoshida MC, Takano T. (1991) Genetic recombination in a chromosomal $\mathrm{t}(2 ; 8)(\mathrm{pl} 1$; q24) of a Burkitt's lymphoma cell line, KOBK101. Gene 97: 239-244.

24. Anderson MLM, Brown L, Kellow JE, Young BD. (1985) Cloning and sequence analysis of an Ig lambda light chain mRNA expressed in the Burkitt's lymphoma cell line EB4. Nucleic Acids Res. 13: 2931-2941.

25. Tsujimoto Y, Croce CM. (1984) Molecular cloning of a human immunoglobulin lambda chain variable sequence. Nucleic Acids Res. 12: 8407-8414.

26. Sun LHK, Croce CM, Showe LC. (1985) Cloning and sequencing of a rearranged Vlambda gene from a Burkitt's lymphoma cell line expressing kappa light chains. $\mathrm{Nu}$ cleic Acids Res. 13: 4921-4934.

27. Carroll WL, Yu M, Link MP, Korsmeyer SL. (1989) Absence of Ig $\mathrm{V}$ region gene somatic hypermutation in advanced Burkitt's lymphoma. J. Immunol. 143: 692-698.

28. Riboldi P, Gaidano G, Schettino EW, et al. (1994) Two acquired immunodeficiency syndrome-associated Burkitt's lymphomas produce specific anti-i IgM cold agglutinins using somatically mutated VH4-21 segments. Blood 83: 2952-2961.

29. Ng VL, Hurt MH, Fein CL, et al. (1994) IgMs produced by two acquired immune deficiency syndrome lymphoma cell lines: Ig binding specificity and VH-gene putative somatic mutation analysis. Blood 83: 1067-1078.

30. Jain R, Roncella S, Hashimoto S, et al. (1994) A potential role for antigen selection in the clonal evolution of Burkitt's lymphoma. J. Immunol. 153: 45-52.

31. Schäble KF, Zachau HG. (1993) The variable genes of the human immunoglobulin $\mathrm{k}$ locus. Biol. Chem. Hoppe-Seyler 374: 1001-1022.

32. Chomczynski P, Sacchi N. (1987) Single-step method of RNA isolation by guanidinium thio- cyanate-phenol-chloroform extraction. Anal. Biochem. 162: 156-160.

33. Sambrook J, Fritsch EF, Maniatis T. (1989) Molecular Cloning. A Laboratory Manual. 2nd Ed. Cold Spring Harbor Laboratory Press, Cold Spring Harbor.

34. Tomlinson IM, Walter G, Marks JD, Llewelyn MB, Winter G. (1992) The repertoire of human germline $\mathrm{VH}$ sequences reveals about fifty groups of $\mathrm{VH}$ segments with different hypervariable loops. J. Mol. Biol. 227: 776-798.

35. Rechavi G, Bienz B, Ram D, et al. (1982) Organization and evolution of immunoglobulin VH gene subgroups. Proc. Natl. Acad. Sci. U.S.A. 79: 4405-4409.

36. Sanz I, Kelly P, Williams C, Scholl S, Tucker P, Capra JD. (1989) The smaller human VH gene families display remarkably little polymorphism. E.M.B.O. J. 8: 3741-3748.

37. Andris JS, Brodeur BR, Capra JD. (1993) Molecular characterization of human antibodies to bacterial antigens: Utilization of the less frequently expressed $\mathrm{VH} 2$ and VH6 heavy chain variable region gene families. Mol. Immunol. 30: 1601-1610.

38. Adderson EE, Azmi FH, Wilson PM, Shackelford PG, Carroll WL. (1993) The human VH3b gene subfamily is highly polymorphic. J. Immunol. 151: 800-809.

39. Berman JE, Mellis SJ, Pollock R, et al. (1988) Content and organization of the human Ig VH locus: Definition of three new VH families and linkage to the $\mathrm{Ig} \mathrm{CH}$ locus. E.M.B.O. J. 7: 727-738.

40. Hieter PA, Maizel JV, Leder P. (1982) Evolution of human immunoglobulin kappa $\mathrm{J}$ region genes. J. Biol. Chem. 257: 1516-1522.

41. Anker R, Caldwell J, Brokaw J, Pollok BA. (1989) Characterization of immunoglobulin mRNA expression in Burkitt lymphoma cell lines. Int. J. Cancer 43: 930-935.

42. Klein R, Jaenichen R, Zachau HG. (1993) Expressed human immunoglobulin $\kappa$ genes and their hypermutation. Eur. J. Immunol. 23: 3248-3271.

43. Cogne M, Mounir S, Mahdi T, Preud'homme JL, Guglielmi P. (1990) Production of an abnormal $\boldsymbol{\mu}$ chain with a shortened VHIV subgroup variable region in a Burkitt's lymphoma cell line. Mol. Immunol. 27: 929-934.

44. Cogne $M$, Mounir $S$, Aucouturier $P$, Preud'homme JL, Nau F, Guglielmi P. (1990) Immunoglobulin light chain transcripts with altered $\mathrm{V}$ regions in Burkitt's 
lymphoma cell lines producing short $\mu$ chains. Eur. J. Immunol. 20: 1905-1910.

45. Jäck H, Berg J, Wabl M. (1989) Translation affects immunoglobulin mRNA stability. Eur. J. Immol. 19: 843-847.

46. Rowe M, Rooney CM, Edwards CF, Lenoir GM, Rickinson AB. (1986) Epstein-Barr virus status and tumour cell phenotype in sporadic Burkitt's lymphoma. Int. J. Cancer 37: 367-373.

47. Liu YJ, Johnson GD, Gordon J, MacLennan ICM. (1992) Germinal centres in T-cell-dependent antibody responses. Immunol. Today 13: $17-21$.

48. Logtenberg $\mathrm{T}$, Schutte ME, Ebeling SB, Gmelig-Meyling FHJ, van Es JH. (1992) Molecular approaches to the study of human B-cell and (auto) antibody repertoire generation and selection. Immunol. Rev. 128: 23-47.

49. Reynaud CA, Garcia C, Hein WR, Weill JC. (1995) Hypermutation generating the sheep immunoglobulin repertoire is an antigen-independent process. Cell 80: 115-125.

50. Reynaud CA, Mackay CR, Müller RG, Weill JC. (1991) Somatic generation of diversity in a mammalian primary lymphoid organ: The sheep ileal Peyer's patches. Cell 64: 9951005.

51. Weber JC, Blaison G, Martin T, Knapp AM, Pasquali JL. (1994) Evidence that the VkIII gene usage is nonstochastic in both adult and newborn peripheral $\mathrm{B}$ cells and that peripheral CD5 + adult B cells are oligoclonal. J. Clin. Invest. 93: 2093-2105.

52. Cleary ML, Meeker TC, Levy S, et al. (1986) Clustering of extensive somatic mutations in the variable region of an immunoglobulin heavy chain gene from a human B cell lymphoma. Cell 44: 97-106.

53. Bahler DW, Levy R. (1992) Clonal evolution of a follicular lymphoma: Evidence for antigen selection. Proc. Natl. Acad. Sci. U.S.A. 89: 6770-6774.

54. Chapman CJ, Mockridge CI, Rowe M, Rickinson AB, Stevenson FK. (1995) Analysis of $\mathrm{V}_{\mathrm{H}}$ genes used by neoplastic $B$ cells in endemic Burkitt's lymphoma shows somatic hypermutation and intraclonal heterogeneity. Blood 85: 2176-2181. 